\title{
Evaluation of Water Provision Ecosystem Services Associated with Land Use/Cover and Climate Variability in the Winike Watershed, Omo Gibe Basin of Ethiopia
}

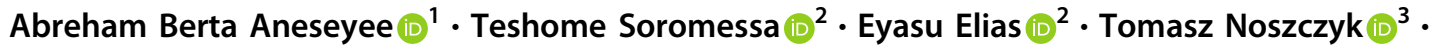 \\ Gudina Legese Feyisa ${ }^{2}$
}

Received: 19 March 2021 / Accepted: 17 November 2021 / Published online: 8 December 2021

(c) The Author(s) 2021

\begin{abstract}
The provision of freshwater is essential for sustaining human life. Understanding the water provision modelling associated with the Land Use/Cover (LUC) change and climatic factors is vital for landscape water resource management. The Winike watershed is the largest tributary in the upper Omo Gibe basin of Ethiopia. This research aims to analyze the spatial and temporal change in the water yield to investigate the water yield contribution from the watershed based on the variation in input parameters. The Integrated Valuation of Ecosystem Services and Tradeoffs Tool (InVEST) water yield model was used to evaluate the spatial and temporal variation of the water yield in different years (1988, 1998, 2008 and 2018). The data required for this model include LUC data from satellite images, reference evapotranspiration, root depth, plant available water, precipitation, season factor ( $Z$ ), and a biophysical table. The analysis of LUC change shows a rapid conversion of grazing land, shrubland, and forest land into cultivated land. There has been a significant variation in water provision, which increased from $1.83 \times 10^{9} \mathrm{~m}^{3}$ in 1988 to $3.35 \times$ $10^{9} \mathrm{~m}^{3}$ in 2018. Sub-watersheds 31,32 , and 39 in the eastern part of the watershed contributed more water due to higher precipitation and lower reference evapotranspiration. The major increase in the contribution of water yield was in built-up land by $207.4 \%$, followed by bare land, $148.54 \%$, and forest land by $63 \%$. Precipitation had a greater impact on water yield estimation compared with the other input parameters. Hence, this research helps decision-makers to make informed decisions regarding new policies for LUC change improvement to maintain the water resources in the Winike watershed.
\end{abstract}

Keywords InVEST model $\cdot$ Land-use change $\cdot$ Spatiotemporal changes $\cdot$ Water yield $\cdot$ Winike watershed

\section{Highlights}

- Spatiotemporal changes in water yield from 1988 to 2018 were investigated.

- The water yield of each LUC was analyzed using the InVEST model.

- The main driver of increased water yield is climate factors.

Supplementary information The online version contains supplementary material available at https://doi.org/10.1007/s00267021-01573-9.

Tomasz Noszczyk

tomasz.noszczyk@urk.edu.pl

1 Department of Natural Resource Management, Wolkite University, Ethiopia, Wolkite, Ethiopia

2 Center of Environmental Science, College of Natural and Computational Sciences, Addis Ababa University, Addis Ababa, Ethiopia

3 Department of Land Management and Landscape Architecture, Faculty of Environmental Engineering and Land Surveying, University of Agriculture in Krakow, Krakow, Poland

\section{Introduction}

The world population depends on water resources for sustaining its life and for economic purposes (Scordo et al. 2018). However, less than $1 \%$ of freshwater is accessible to the global community. Its uneven spatial and temporal distribution, along with overexploitation of water resources by humans, which causes scarcity of water (Mekonnen and Hoekstra 2011), further exacerbate the problem. Anthropogenic activities are major causes of the scarcity of freshwater (Murphy and Kapelle 2014; Szewrański et al. 2018). Economic growth together with population expansion cause land use to change significantly, which leads to 
further degradation of water resources (Assessment 2005; Sharma et al. 2020). This is because human livelihood and economic growth depend on ecosystem services such as food, water, and energy (Casagrande et al. 2021; Sahle et al. 2019). This, in turn, might jeopardize water sustainability due to anthropogenic and natural factors. Climate change has also become a threat to global human populations (Bangash et al. 2013; Gain and Wada 2014).

Water yield is the main regulatory ecosystem service, which contributes to the wellbeing of people, ensuring the development of irrigation, and improvement in the standard of living (Cudennec et al. 2007). Water yield is defined as the maintenance of water by ecosystems within a certain period (Xu et al. 2016). Other authors also defined water yield as the sum of surface runoff from the landscape (Chiang et al. 2019; Tallis et al. 2011). The relative amount of water in a given landscape affects the quality of the environment by either increasing or decreasing land productivity (Shoyama and Yamagata 2014; Srichaichana et al. 2019). Understanding the hydrological processes affected by the land-use change is essential for sustainable water resources management (Narsimlu et al. 2013; Walega and Salata 2019) because LUC changes affect water yield by interrupting the hydrological processes within the landscape (Aghsaei et al. 2020; Assessment 2005; Gebremicael et al. 2013; Gwate et al. 2015). Some examples of the effects that LUC change has been decreased streamflow due to the growth of agricultural land causing water withdrawal for irrigation and urban consumption (Bian et al. 2017); surface runoff reduction by $22 \mathrm{~mm}$ over 20 years due to the upstream land-use change (increase in forest land and grassland areas) in the Loess Plateau of China (Yan et al. 2018; reduced Alento River Catchment (UARC, southern Italy)) water yield and its actual evapotranspiration increased due to afforestation (Nasta et al. 2017); maximized runoff and minimized recharge of groundwater after grassland was replaced by agriculture and bare land in the Zanjan Rood catchment, Iran (Ghaffari et al. 2010); and progressive urban development affecting the hydrologic cycle in the Prądnik River basin, Poland (Lepeška et al. 2020). Moreover, findings by Lotz et al. (2018) in China also showed that the conversion of agricultural land into forest decreased water yield. However, vegetation type, precipitation intensity, soil permeability, topography, and geomorphology are complex factors that affect water yield assessment as well (Zhang et al. 2012).

National resource management policies, rapid socioeconomic growth, and climate instability are key factors leading to LUC change (Dwarakish and Ganasri 2015). Particularly in areas where the availability of water is too low, alterations in LUC result in water scarcity and water quality deterioration. Therefore, evaluating the effect of the LUC and climate change on water yield is vital for the sustainable management of a river basin (Ahiablame and Shakya 2016).

Reliable modelling of watershed processes is a critical part of aiding decision-makers and managers to sustain and improve ecosystem services (such as recreational opportunities, drinking water supply, and energy production) (Schröter et al. 2005). Various hydrologic models (Bieger et al. 2015) and land-cover data sources (Walega and Salata 2019) were used to assess the impacts of LUC change on the hydrologic response in a landscape. Among these models, the Integrated Valuation of Ecosystem Service and Trade-offs (InVEST) water yield model has been commonly applied to assess water provision associated with LUC change within a landscape. It can be useful for supporting decision-making (Arunyawat and Shrestha 2016) and has been widely used for a variety of research and planning applications (Bai et al. 2013; Bangash et al. 2013; Boithias et al. 2014). Besides, mapping and quantifying of water provision is used to avoid unintended impacts on the provision and production of services (Bastola et al. 2019).

The InVEST water yield model has easily operated software, minimum data needs, and computer requirements. Still, it offers more explicit output data for an annual timeframe and is suitable for areas with inadequate data coverage (Ibrahim et al. 2015; Komi et al. 2017; Vogl et al. 2016). It is a widely-used open-source tool available for free and appropriate for ecosystem service modelling (Redhead et al. 2016). The quick water yield generation for large geographical areas and spatially explicit nature of the model could facilitate the decision-making process by demonstrating the degradation of water resources. This could be achieved by identifying hotspots potentially in need of a vital intervention in land management and increased monitoring of hydrological ecosystem services at minimum costs (Dimobe et al. 2015; Lüke and Hack 2018; Vogl et al. 2016). These characteristics made the model attractive to use as compared to some complex hydrological models such as SWAT (Soil and Water Assessment Tool).

In the Omo Gibe basin of Ethiopia, four dams (I, II, III, and IV) are constructed and fifth and sixth were proposed, which would significantly contribute to the green economy of Ethiopia by generating $2800 \mathrm{MW}$ of power (Aneseyee et al. 2019). This is possible because the basin has potential sources of water and many tributaries. However, human factors such as sedimentation, deforestation, agricultural exploitation, invasive species, urbanization, and pollution coupled with climate change have become a threat and harmed important ecosystem services such as water yield (Aneseyee et al. 2020). Some hydrological modelling research projects focusing on SWAT 
have been undertaken for the Omo Gibe basin; such as those by Choto and Fetene (2019), Estifanos and Gebremariam (2019), Takalaa and Tamamc (2016) and Chaemiso et al. (2016). However, the majority of previous research attempts on the availability of water in the Omo Gibe basin was limited (Chaemiso et al. 2016). Some of the gaps in the current knowledge can be summarized as follows: (1) While the ecosystem services assessment has made significant progress in recent decades, existing methods largely focus on estimating the total output from ecosystems (Martín-López et al. 2014; Yang et al. 2020a), which cannot reflect the ecosystems in full spectrum; they cannot distinguish ecosystems with the same assessment results but of various sizes (Shi et al. 2021). (2) In terms of a temporal scale, few studies followed a long, continuous timeline (over 20 years). Most existing research is limited to a short period (Shi et al. 2020; Xie et al. 2017). (3) Even though numerous studies target ecosystem services, quantitative relationships between influencing factors and ecosystem services have not been pinpointed (Ren et al. 2020).

Therefore, compared with previous studies, the objectives of this paper are (1) to analyze the spatial and temporal changes in water yield over the last 30 years; (2) to investigate the contribution of the watershed's water yield to the main river for hydropower production; (3) to compare the impact of LUC change and climate variability on water yield, and 4) to prioritize the sub-watershed's water yield and validate the model's performance.

The authors decided to tackle the evaluation of water provision ecosystem services in their study because although similar investigations have often been the core issue of research (Shi et al. 2021; Stosch et al. 2017; Vardon et al. 2019), they have been relatively rare in Ethiopia and the north-eastern part of Africa. What is more, the land use/cover and climate data are broadly applied and help identify anthropogenic changes in space and watersheds.

The authors believe the study offers universal values and a valuable contribution of new knowledge of the evaluation of water provision ecosystem services from the international point of view. The novelty of this research is the field assessments and laboratory analysis supported by GIS and remote sensing, resulting in water yield potential (temporal and spatial). The InVEST water yield model used in the study is a foundation for further comparative analyses based on appropriate expert opinions. It may be applied to other areas where data on land use/cover and climate are available. The spatial evaluation of water resources at the watershed level under LUC and climate change scenarios can help identify vulnerable locations for adequate adaptation, planning, and implementation of responses. Therefore, this study is innovative and important for mapping water yield, water consumption, and water supply.

\section{Materials and Methods}

\section{Study Area}

The study site is located in the regions of the Southern Nations, Nationalities, and Peoples' Region state (SNNPR) of Ethiopia within the basin of Omo Gibe with coordinate bounds of $7^{\circ} 40^{\prime} \mathrm{N}$ to $8^{\circ} 20^{\prime} \mathrm{N}$ and $37^{\circ} 40^{\prime} \mathrm{E}$ to $38^{\circ} 10^{\prime} \mathrm{E}$ and a total area of $1091.8 \mathrm{~km}^{2}$ (Fig. 1). The Winike River is one of the tributaries of the Omo Gibe basin situated in five districts of the Guraghe zone and one district of the Silte zone.

Its lowest altitude is $1022 \mathrm{~m} \mathrm{ASL}$ at the Gibe gorge and the highest altitude, $3324 \mathrm{~m}$ ASL in the Bozebar area of the watershed. Its slope gradients vary from zero to $89.9^{\circ}$. The annual rainfall varies from $856 \mathrm{~mm}$ to $1600 \mathrm{~mm}$ with a bimodal distribution with a mean annual total of $1753 \mathrm{~mm}$ (Fig. 2). June to September is the main rain season (summer), and March to April is the short rain season, which is spring. This season can provide rain that is sufficient for farming. The maximum and minimum mean temperature values are 26.8 and $6.6^{\circ} \mathrm{C}$, respectively, with a mean temperature of $17.7^{\circ} \mathrm{C}$. The upper part of the watershed is dominated by Eucalyptus plantations, whereas the lower part is occupied by Acacia vegetation (Acacia polyacantha) and grassland.

\section{The InVEST Water Yield Model}

The InVEST water yield model (Hydropower/Water Yield, InVEST v3.6.0) was used to analyze the water yield in the watershed. It also demonstrated the watershed contribution to hydropower production (Sharp et al. 2018) and the downstream ecosystems. The InVEST water yield model input data were pre-processed in ArcGIS to normalize pixel size before using them in the model (Table 1).

The total annual water yield (Y) in the study watershed was estimated by the annual rainfall (P) minus the actual annual evapotranspiration (AET) (Eq. 1). In other words, the difference between all water falling as precipitation over the watershed and evapotranspiration loss from the watershed. We used Eq. (1) by Budyko et al. (1974) to calculate the annual water provision $(\mathrm{Y}(\mathrm{x}))$ for a pixel of the landscape $(\mathrm{x})$.

$$
Y(x)=\left(1-\frac{A E T(x)}{P(x)}\right) P(x)
$$




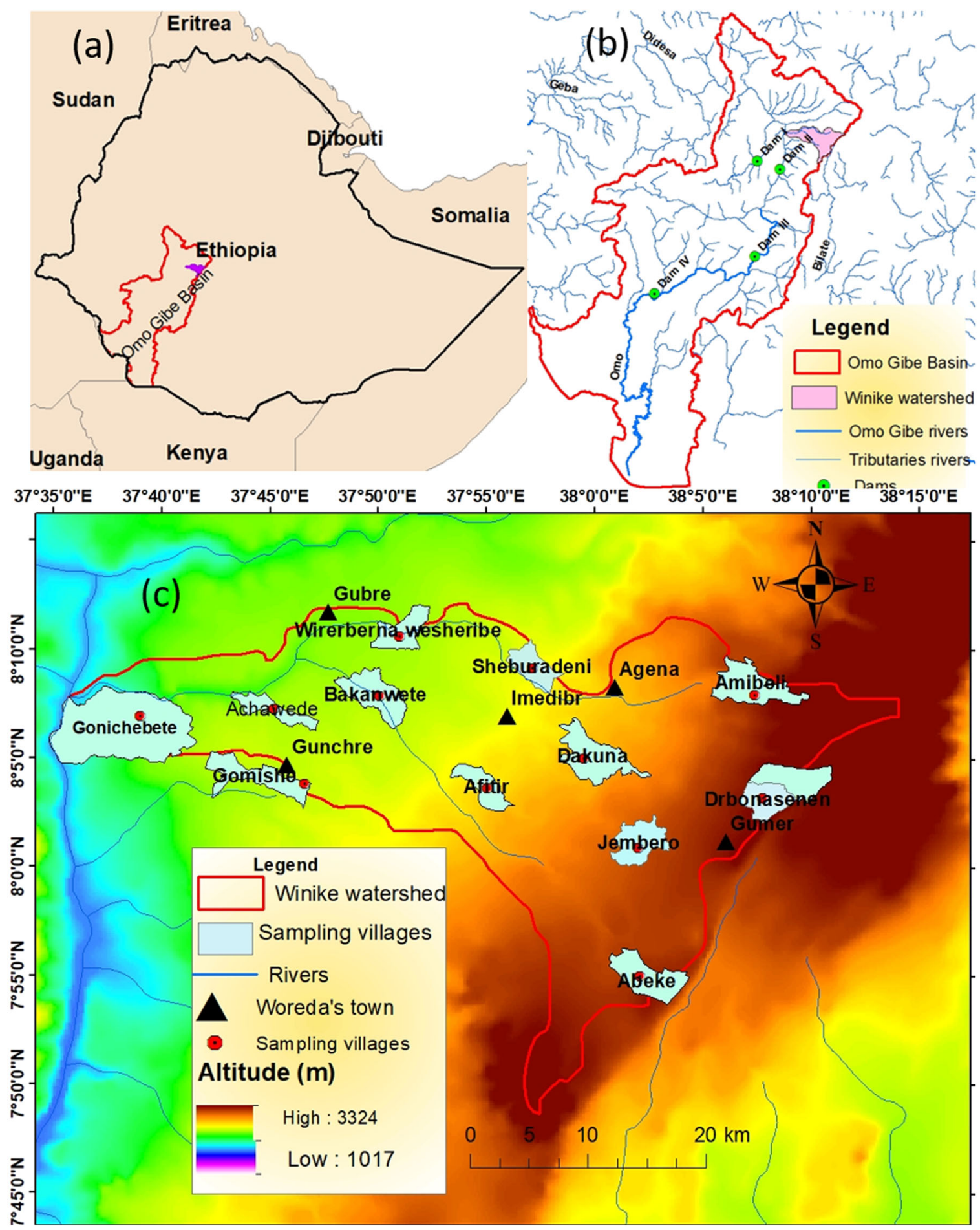

Fig. 1 Map of the watershed. Watershed in Ethiopia (a) and hydropower dams (b) showing the sub-watersheds (c) (sampling villages are used to collect the local Ecosystem services valuation data)

where $\operatorname{AET}(\mathrm{x})$ - the actual annual evapotranspiration in pixel $\mathrm{x}$ and $\mathrm{P}(\mathrm{x})$ - the annual precipitation in pixel $\mathrm{x}$.

For vegetative LUC, the evapotranspiration portion of the water balance $\left(\frac{\operatorname{AET}(x)}{\mathrm{P}(\mathrm{x})}\right)$ is analyzed based on the Budyko curve supported by Fu (1981) and Zhang et al. (2004) given in Eq. (2).

$\frac{\mathrm{AET}(\mathrm{x})}{\mathrm{P}(\mathrm{x})}=1+\frac{\mathrm{PET}(\mathrm{x})}{\mathrm{P}(\mathrm{x})}-\left[1+\left(\frac{\mathrm{PET}(\mathrm{x})}{\mathrm{P}(\mathrm{x})}\right)\right]^{\omega * 1 / \omega}$ 
where PET $(x)$ - the potential evapotranspiration and $\omega(x)-$ a non-physical parameter that shows the natural properties of the soil climate zone.

Potential evapotranspiration (x) is calculated with Eq. (3)

$$
\operatorname{PET}(\mathrm{x})=\operatorname{Kc}(\mathrm{x}) \times \operatorname{ETo}(\mathrm{x})
$$

where $\mathrm{Kc}(\mathrm{x})$ - the coefficient of LUC evapotranspiration used to adjust for reference evapotranspiration (the value is provided in Table $\mathrm{S} 1$ ) and $E T_{0}(\mathrm{x})$ - the annual reference evapotranspiration per pixel $\mathrm{x}$.

The non-physical parameter, $\omega(\mathrm{x})$, proposed by Donohue et al. (2012) for the InVEST model, is calculated with Eq. (4)

$\omega(\mathrm{x})=\mathrm{Z} \frac{\mathrm{PAWC}(\mathrm{x})}{\mathrm{P}(\mathrm{x})}+1.25$

where $\mathrm{Z}$ - the season factor and PAWC - Plant Available Water Content

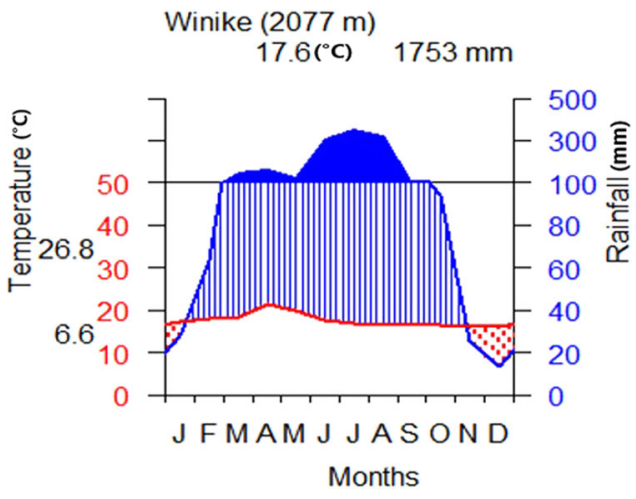

Fig. 2 Climatogram for the watershed (the climate data analysis based on data from 1988 to 2018)
Input data pre-processing for the model

All the required input datasets for the InVEST water yield model were (Table 1) projected using the Universal Transverse Mercator (UTM) of WGS84 zone $37^{\circ} \mathrm{N}$ and be resampled with a spatial resolution of $30 \mathrm{~m}$. The images were terrain-corrected projected to the Universal Transverse Mercator (UTM).

GIS and land use/cover analysis Landsat satellite images for the years 1988 (Landsat 5), 1998 (Landsat 5), 2008 (Landsat 7), and 2018 (Landsat 8) were obtained from the United States Geological Survey (USGS) data portal (https://earthexplorer.usgs.gov) to analyze the LUC. The selected images were taken in the dry season when the monthly cloud cover is the lowest. Due to the failure of the Scan Line Corrector (SLC) in 2003, the 2008 images acquired by the sensor exhibit data gaps (striping). Hence, we applied image gap-filling using a gap-filling tool in ENVI v5.3.

Radiometric calibration to reflectance value, geometric correction, and Quick Atmospheric A correction algorithm was applied to the images before they were classified. A supervised image classification method was employed using the Mahalanobis distance classification, and the Ground Reference Points (GRP) data were collected using a GPS receiver to convert a vector file. Then, a Region of Interest (ROI) was determined in ENVI v5.3 software. Using the ROI, the spectral signature of each LULC type has been extracted. Based on the analysis and gathered information, eight types of LUCs were categorized. An error matrix such as accuracy assessment was analyzed to indicate the reliability of the LUC classification and validation. The Kappa coefficient was also used to show the conformity of the classified image with the reference data.
Table 1 Data required for the InVEST water yield model

\begin{tabular}{|c|c|c|c|}
\hline Categories of data & Types & Sources & $\begin{array}{l}\text { Range of sensitivity } \\
\text { analysis }\end{array}$ \\
\hline $1 \mathrm{LUC}^{\mathrm{a}}$ & Raster & United State of Geological Survey & $\mathrm{n} / \mathrm{a}$ \\
\hline 2 Temperature data ${ }^{a}$ & Numeric & National Mereology Agency & $\mathrm{n} / \mathrm{a}$ \\
\hline 3 Watershed & Vector & EthioGIS & $\mathrm{n} / \mathrm{a}$ \\
\hline 4 Sub-watersheds & Vector & Digital elevation model & $\mathrm{n} / \mathrm{a}$ \\
\hline 5 Root depth & Raster & Yang et al. (2016) & \pm 10 \\
\hline $6 \mathrm{ET}_{0}^{\mathrm{a}}$ & Raster & Hargreaves and Allen (2003) & \pm 10 \\
\hline 7 Precipitation $^{\mathrm{a}}$ & Raster & National Mereology Agency & \pm 10 \\
\hline 8 Plant available water content & Raster & Laboratory analysis & \pm 10 \\
\hline 9 Consumptive water & Numeric & Field survey & $\mathrm{n} / \mathrm{a}$ \\
\hline $10 \mathrm{Z}$ & Constant & Sharp et al. (2018) & \pm 10 \\
\hline $11 \mathrm{Kc}$ & Numeric & Allen et al. (1998) & \pm 10 \\
\hline
\end{tabular}

${ }^{a}$ Average data used for the years $(1988,1998,2008$, and 2018) 
Fig. 3 Input parameters for the InVEST water yield model. a Precipitation, b reference evapotranspiration, $\mathbf{c}$ plant available water content, and $\mathbf{d}$ root depth

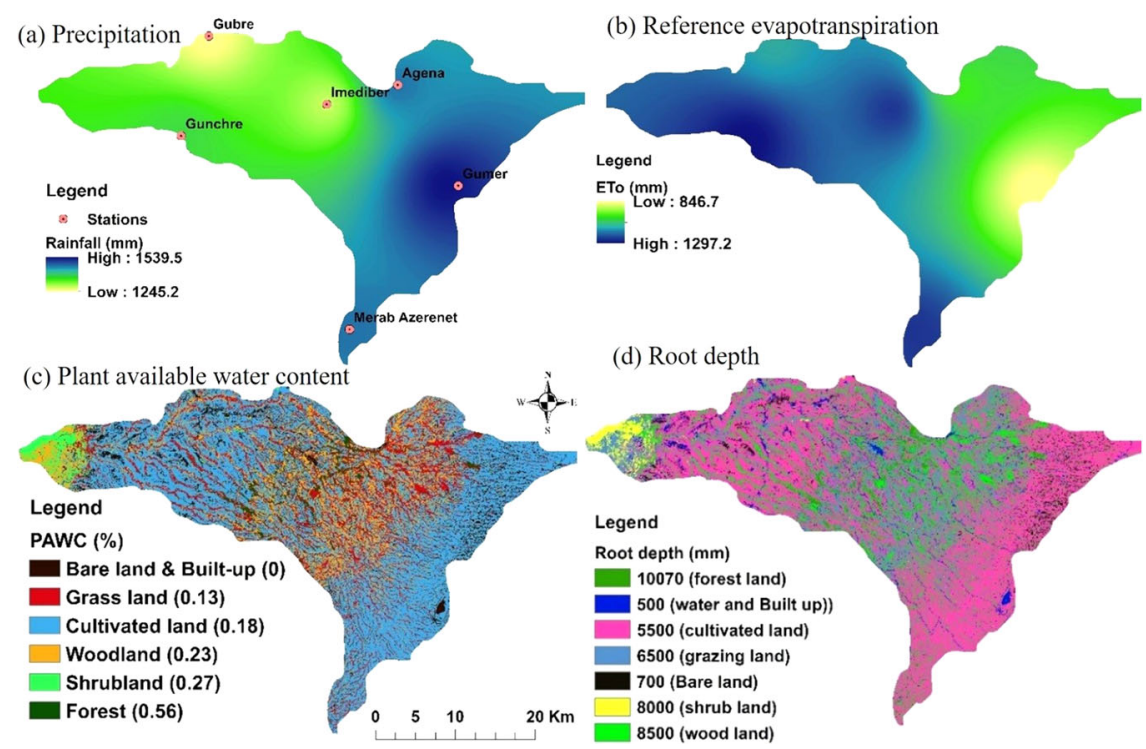

Root depth Rooting depth $(\mathrm{cm})$ is the accessible soil profile for water storage. It is defined as the soil depth at which $90 \%$ of root biomass occurs. The study watershed root depth was determined based on carbon cost-benefit model developed by Guswa (2008) and Yang et al. (2016). The carbon cost-benefit model incorporates seven parameters; the root respiration, root length density, specific root length, photosynthetic water use efficiency, the fraction of growing season within a year, and mean annual transpiration rate for a given root depth.

Reference evapotranspiration ( $\mathrm{ET}_{0}$ ) The reference evapotranspiration was estimated based on the modified Hargreaves method (Hargreaves and Allen 2003) using Eq. (5). The Hargreaves method requires the parameter of precipitation, maximum and minimum average temperatures, and extraterrestrial radiation (RA) (mm/day). Thirty-year (30) data on rainfall and temperature were obtained for the watershed from the National Meteorology Agency (NMA) of Ethiopia. The RA was determined in the $\mathrm{R}$ software Package SPEI (Guo et al. 2016), by inputting the latitudinal location of the watershed (Table S2).

$$
\begin{aligned}
E T_{0}= & 0.0013 \times 0.408 \times \mathrm{RA} \times\left(T_{\text {mean }}+17\right) \\
& \times(T D-0.0123 \times P)^{0.76}
\end{aligned}
$$

where $\mathrm{T}_{\text {mean }}$ - the average daily temperature (average of the mean daily maximum and minimum temperature $\left({ }^{\circ} \mathrm{C}\right)$ ); $\mathrm{RA}$ - the extraterrestrial radiation (mm/day); $\mathrm{ET}_{0}-$ the reference evapotranspiration; and TD - the temperature ranges $\left({ }^{\circ} \mathrm{C}\right)$.

The interpolation technique of IDW (inverse distance weighted) in ArcGIS v10.4 (ESRI, Inc., Redlands, CA, USA) was used to generate a raster spatial map for the mean annual $\mathrm{ET}_{0}(\mathrm{~mm})$ and $\mathrm{P}(\mathrm{mm})$ values for the InVEST model input (Fig. 3a, b).

Plant available water content (PAWC) Plant Available Water Content (PAWC) is the volumetric $(\mathrm{mm})$ plant available water content, expressed as the rate of water that can be held in the soil for use by vegetation (Fig. 3c). The estimation of PAWC developed by Zhou et al. (2005), based on soil texture (sand\%, silt\%, and sand\%) and Organic Matter (OM) content in the soil for each LUC type is calculated using Eq. 6 .

$$
\begin{aligned}
P A W C= & 54.509-0132 \times \text { sand }-0.003 \times(\text { sand })^{2} \\
& -0.055 \times \text { silt }-0.006 \times(\text { silt })^{2}-0.738 \\
& \times \text { clay }+0.007 \times(\text { clay })^{2}-2.688 \\
& \times \text { OM }+0.501 \times(\text { OM })^{2}
\end{aligned}
$$

These soil parameters were analyzed in the Wolkite soil laboratory by taking 100 soil samples of representative land-use types.

Season factor (Z) The season factor $(Z)$ is estimated with three different methods. The first method is for calculating the $\mathrm{Z}$ parameter from an available $\omega$ parameter $(\mathrm{Xu}$ et al. 2013) using the rearranged Eq. (3) as $\mathrm{Z}=\frac{(\omega-1.25) P}{\text { PAWC }}$ and its value is 32 . The second way to determine the season factor $(\mathrm{Z})$ is to take $1 / 5$ of the number of rain events $(\mathrm{N})$ per year $(0.2 * \mathrm{~N})$ (Donohue et al. 2012). The number of rainfall events (N) was determined with Ethiopian National Meteorology Agency (NMA) data, which indicates that the mean number of rainy days per year in the Winike watershed was approximately 145 . Thus, the $Z$ parameter value is 29. The third method is based on observed and calibrated 
streamflow data for the last 30 years, which resulted in the average $Z$ value of 12 . Of course, the $Z$ parameters would be estimated in different sources. However, the second method was used to estimate explicitly the overall spatial and temporal water yield model since it best reflected the reality of the Ethiopian environment, but the first and the third were somehow complicated to get the precise data for Ethiopia. Moreover, the three values were used for sensitivity analysis of the water yield similarly to the sensitivity analysis for precipitation and evapotranspiration.

\section{Water yield contribution by the watershed}

According to Sharp et al. (2018), the actual amount of water from the watershed that reaches the dam reservoir (realized supply (d)) is calculated as a difference between the total water yield and consumptive water use (Eq. 7). For this analysis, we prepared a demand table with input for the InVEST model to show how much water is consumed by each land use/cover type. We investigated water consumed by agriculture and urban land. Therefore, each land-use type in the watershed either contributes to hydropower production or consumes water.

$$
V_{\text {in }}=Y-U_{d}
$$

where $V_{\text {in }}$ - the realized supply (volume of water inflow to a reservoir from upstream of the watershed), $U_{d}-$ the total anthropogenic water consumption in the watershed, and $Y-$ the total water yield, calculated with the InVEST model.

We investigated water consumed by agriculture and urban land. Industrial withdrawals which are not returned to the water body are recognized in urban land. Three private water abstraction companies producing bottled drinking water are located in the Winike watershed. These water packing companies are Aden, Fiker, and Waw. Their approximate annual water withdrawal rate was determined by consulting each of the water company offices.

In urban land, consumptive use can be calculated as the product of population density and per capita consumptive use. Therefore, data on water consumed by individual households for their daily activities was collected through a $\mathrm{HH}$ survey by selecting twelve (12) villages (kebeles) from six districts using purposive sampling. A sample of households was investigated with the Cochran and Banner (1977) formula. Thus, human water consumption was estimated based on individual water usage (1/day/person) multiplied by the size of the population in the watershed.

Water used by livestock that is not returned to the reservoir must be considered for agricultural land. According to Sileshi et al. (2003), the annual water requirement for sheep and goats is $0.011 \mathrm{~m}^{3} /$ day, cattle consumption is $0.045 \mathrm{~m}^{3} / \mathrm{day}$, and consumption by horses, mules, camels, or assess is $0.045 \mathrm{~m}^{3} /$ day. The population data for the livestock was obtained from the Guraghe Zone Department of Finance and Economic Development (GZDFED) (2016) of Ethiopia. The total water consumption by livestock was calculated from the number of livestock specimens multiplied by individual livestock water consumption value, according to Sileshi et al. (2003).

\section{Model sensitivity}

InVEST water yield model uncertainty originated from the uncertainty of climate data (i.e., the variability of precipitation and reference evapotranspiration) (McGlynn et al. 2012; McMahon et al. 2013; Sahle et al. 2019). Therefore, checking the credibility of the source data for precipitation and PET helps reduce the error in the modelled water yield.

The available climate data obtained from the different sources located over the watershed might have generated an error of \pm 10 for the water yield analysis (Hamel and Guswa 2015). This shows that the water yield result changes significantly for a $10 \%$ change in the value of parameters, and the model is highly sensitive to errors as regards estimating water yield. Therefore, applying uniformly $\pm 10 \%$ to each water yield input model parameter in the baseline climate input data across the landscape explicitly shows efficient decision-making on regulating water provision (Hamel and Guswa 2015). Finally, the models were run independently using the InVEST model for each of these parameters' variations to determine whether or not each parameter had a significant effect on water yield results.

\section{Model validation}

To verify the applicability and reliability of the model, we validated the exported InVEST water yield results against observed water yield available from Ethiopian Ministry of Water, Irrigation, and Energy (MOWIE) data (1988-2018). The output of the InVEST water yield model was provided in $\mathrm{m}^{3} /$ year and the observed streamflow data was expressed in $\mathrm{m}^{3} / \mathrm{s}$. For consistent analysis, the observed data had to be converted to $\mathrm{m}^{3} /$ year based on the streamflow $\left(\mathrm{m}^{3} / \mathrm{s}\right)$ data from five gauging stations.

The Coefficient of Determination $\left(\mathrm{R}^{2}\right)$, Residual Root Mean Square (RRMSE), Nash-Sutcliffe Efficiency (NSE), and average Percentage Bias Error (PBIAS) (Eqs. 8 to 11) were used to validate the performance of the model (Gyamfi et al. 2016; Munoth and Goyal 2019). This was necessary to determine the applicability of the InVEST water yield model for the watershed.

$\operatorname{RRMSE}=\frac{\sqrt{\frac{1}{n}} \sum_{j=1}^{n}\left(\mathrm{P}_{\mathrm{i}}-\mathrm{O}_{\mathrm{i}}\right)^{2}}{\sum_{i=1}^{n} \frac{O_{i}}{\mathrm{n}}}$ 
$\mathrm{R}^{2}=\left\{\frac{\sum_{i=1}^{n}\left(\mathrm{O}_{\mathrm{i}}-\mathrm{O}_{\mathrm{ave}}\right) \times\left(\mathrm{P}_{\mathrm{i}}-\mathrm{O}_{\mathrm{ave}}\right)}{\left[\sum_{i=1}^{n}\left(\left(\mathrm{O}_{\mathrm{i}}-\mathrm{O}_{\mathrm{ave}}\right)\right)^{2}\right]^{0.5} \times\left[\sum_{i=1}^{n}\left(\mathrm{P}_{\mathrm{i}}-\mathrm{P}_{\mathrm{ave}}\right)^{2}\right]^{0.5}}\right\}^{2}$

Bias $=\frac{\sum_{i=1}^{n} \mathrm{P}_{\mathrm{i}}-\sum_{i=1}^{n} \mathrm{O}_{\mathrm{i}}}{\sum_{i=1}^{n} \mathrm{O}_{\mathrm{i}}} \times 100 \%$

$\mathrm{NSE}=1-\frac{\sum_{-=1}^{n}\left(P_{i}-O_{i}\right)^{2}}{\sum_{-=1}^{n}\left(P_{i}-O_{A v e}\right)^{2}}$

where, $\mathrm{O}_{\mathrm{i}}-$ Observed data, $\mathrm{P}_{\mathrm{i}}-$ predicted data, $\mathrm{O}_{\text {ave }}-$ the average of the observed, $\mathrm{P}_{\mathrm{ave}}$ - the average of the predicted, and $\mathrm{n}$ - sample count.

\section{Water yield (WY) coefficient}

The WY coefficient represents water availability in the various categories of land use. For each form of LUC, it can be determined using Eq. 12 ( $\mathrm{Li}$ et al. 2018). The WY coefficient also shows the water yield conversion resulting from precipitation due to the effects of infiltration, saturation, and evapotranspiration (Singh et al. 2011). Climate variations were taken into account when determining the coefficient of water yield for each type of LUC.

Water yield $(\mathrm{WY})$ coefficient $=\frac{\mathrm{WY}}{\text { precipitation }}$

\section{LUC and climate variability effect on water provision}

The main drivers for the change in water yield could be climate variability and LUC change. However, specific scenarios were considered to determine which one affected the change in water yield in the Winike watershed more. To this end, a scenario (1) without climate variability and a scenario (2) without LUC change were input into the InVEST water yield model. Under scenario (1), only LUC change was considered. Therefore, LUC data for 1988, 1998, 2008, and 2018 were provided as the input for the respective years. However, meteorological data were not recognized in the model in Scenario (1). In scenario (2), the raster reference evapotranspiration $\left(\mathrm{ET}_{0}\right)$ and precipitation for 1988, 1998, 2008, and 2018 were provided as input. LUC data were not considered in the model in Scenario (2). The remaining model input parameters such as biophysical CSV table, season factor (Z), and water demand table were constant in the two scenarios. The two scenarios were run independently for each year using the InVEST water yield model based on the provided data.

\section{Results and Discussion}

\section{Land Use/Cover Change}

The LUC analysis for 1988, 1998, 2008, and 2018 shows a massive conversion of LUC (Fig. 4). For example, forest and grazing land declined by $35.56 \%$ and $49.12 \%$, respectively, whereas cultivated land grew by $33.01 \%$ (Table 2), which is indicative of a large-scale conversion of grazing and forest area into cultivated land in the last 30 years. Moreover, built-up and bare land increased by $109.58 \%$ and $65.19 \%$, respectively. The major reason for the land dynamics in the investigated area could be an increase in population pressure, which led to the expansion of agricultural land through clearance of vegetated land and continuous ploughing of the existing agricultural land without fallowing and other conservation practices. Woodland also increased by $4.25 \%$ because of an expanding Eucalyptus plantation. It is of significant economic value to local farmers, greater than other crops. The change of grazing land and forest land into cultivated fields amounted to $19 \%$ and $1.84 \%$, respectively, while the conversion of cultivated land into forest land was insignificant. Nevertheless, cultivated land was converted into grazing land by $7.07 \%$. Overall, $45.89 \%$ of the land has never changed; for example, 31.79 thousand hectares (29\%) of cultivated land have not changed for the last 30 years.

\section{Water Yield Change in the Watershed}

The spatial water yield was evaluated for different years, 1988, 1998, 2008, and 2018 (Fig. 5). The total annual water provision increased from $1.83 \times 10^{9} \mathrm{~m}^{3}$ in 1988 to $3.35 \times$ $10^{9} \mathrm{~m}^{3}$ in 2018 , which is an increase of $83.21 \%$ in the last 30 years. In 1988, the water yield ranged from $2362 \mathrm{~m}^{3} / \mathrm{ha}$

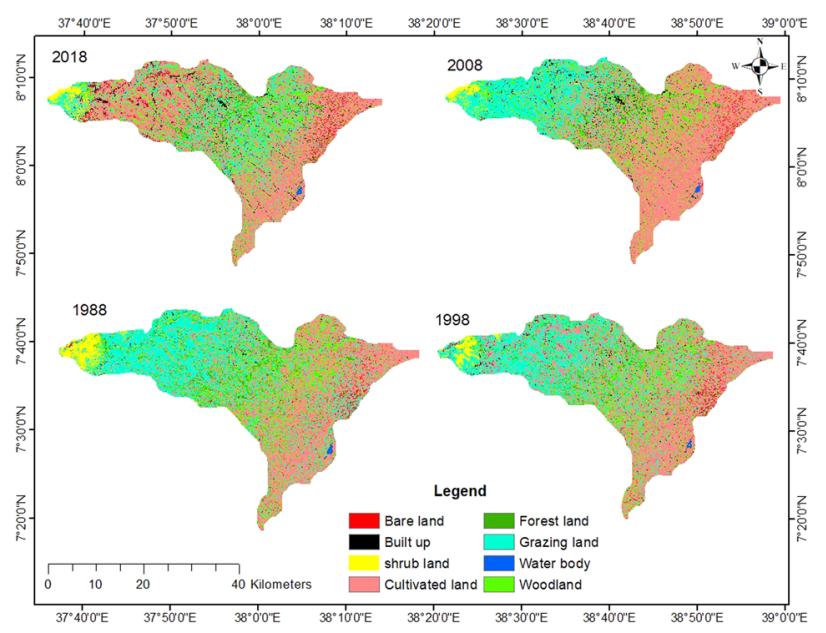

Fig. 4 Maps of Land use and land cover changes for the reference years 
Table 2 The land use/cover changes per hectare in the last 30 years
Fig. 5 Spatial distribution of the mean water yield $\left(\mathrm{m}^{3} / \mathrm{ha} /\right.$ year $)$ for sub-watersheds

\begin{tabular}{lcccccc}
\hline LULC & 1988 & 1998 & 2008 & 2018 & Change (ha) & Change (\%) \\
\hline Bare land & 1517.49 & 1612.26 & 1804.59 & 2506.68 & 989.19 & 65.19 \\
Built-up land & 1891.23 & 1427.22 & 2744.28 & 3963.6 & 3377.43 & 109.58 \\
Shrubland & 3245.22 & 2324.61 & 1816.02 & 2030.04 & -1215.18 & -37.45 \\
Cultivated land & 44954.5 & 51892.2 & 57442.5 & 59792.9 & 14838.4 & 33.01 \\
Forests & 7353.72 & 5209.74 & 4466.79 & 4738.86 & -2614.86 & -35.56 \\
Grazing land & 32876.3 & 30243 & 23267.3 & 16728.3 & -16148 & -49.12 \\
Water bodies & 252.18 & 254.34 & 280.98 & 242.01 & -10.17 & -4.03 \\
Woodland & 18397 & 16219.2 & 17360.1 & 19180.1 & 783.1 & 4.26 \\
\hline
\end{tabular}

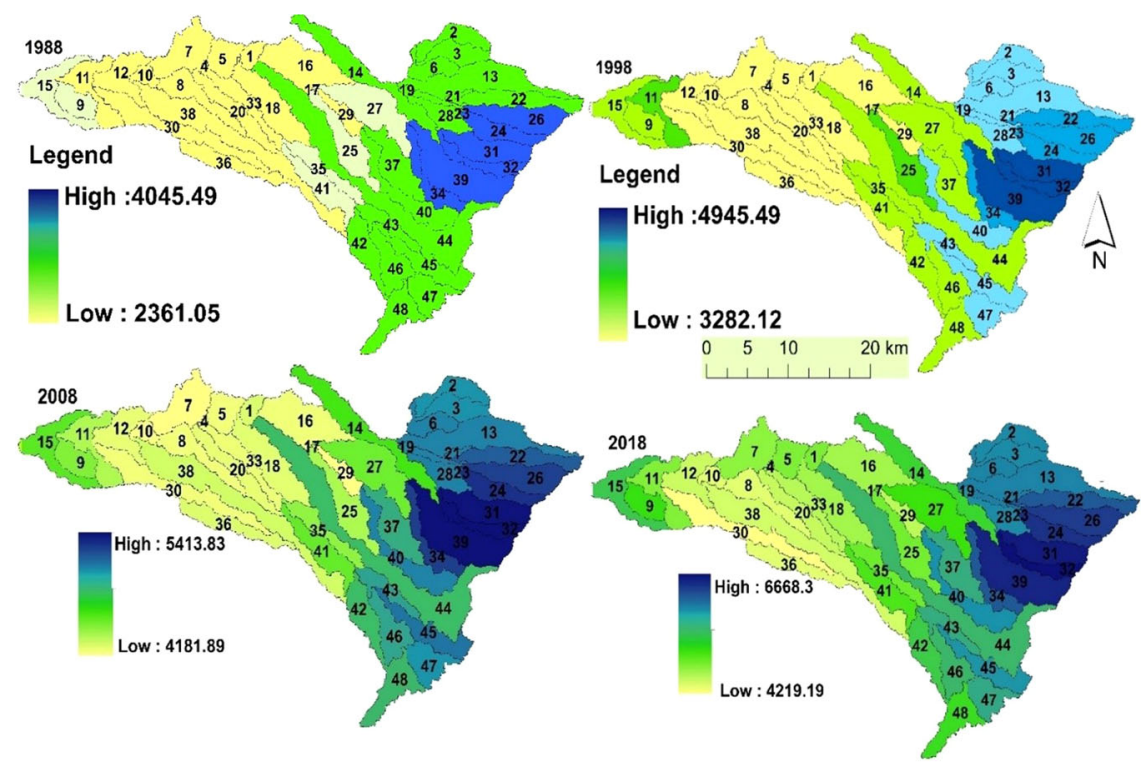

to $4045 \mathrm{~m}^{3} / \mathrm{ha}$, with an average below $2800 \mathrm{~m}^{3} / \mathrm{ha}$. In 2018 , the water yield was $4219 \mathrm{~m}^{3} /$ ha to $6668 \mathrm{~m}^{3} / \mathrm{ha}$, with a mean of $5130 \mathrm{~m}^{3} / \mathrm{ha}$. Spatially, the greatest water provision in the last three decades was found in the eastern part of the watershed.

We recognize that there is a significant difference in the water yield model in every sub-watershed (SW) because of the differences in the climatic scenarios for the area. Subwatersheds 31,32 , and 39 in the eastern part of the watershed contributed more water than the other sub-watersheds, with a mean value of $6589.32 \mathrm{~m}^{3} / \mathrm{ha} /$ year, $6670.56 \mathrm{~m}^{3} / \mathrm{ha} /$ year, and $6579 \mathrm{~m}^{3} /$ ha/year, respectively. Sub-watersheds 8 , 29 , and 30 provided the smallest amounts of water in each reference year for the last three decades. The higher-altitude area (eastern part of the watershed) also encompassing SW24, SW26, SW31, SW32, and SW39 had higher precipitation and lower temperatures (meteorological data analysis around these SWs recorded lower temperatures), and the water yield is correspondingly higher there. Moreover, precipitation was relatively high $(1528 \mathrm{~mm})$, and AET and PET were low (578 $\mathrm{mm}$ and 589, respectively) in SW32, while in sub-watershed 30 precipitation was the lowest $(1366.5 \mathrm{~mm})$ and AET and PET were $660 \mathrm{~mm}$ and $678 \mathrm{~mm}$, respectively. Therefore, the differences in precipitation, incoming solar radiation, and temperature might cause significant changes in the water yield in the landscape. These conclusions are consistent with similar research findings by Yang et al. (2020b) in northwest China.

Water yield conversion from one sub-watershed to another was noted from 1988 to 2018. The average water yield in each sub-watershed from 1988 to 2018 indicated a constant and increasing trend. For example, water yield in SW1, SW4, SW5, SW12, and SW16 was lower between 1988 and 2008, but it started an increasing trend in 2018 while in SW8, SW29 and SW30, it was constantly the lowest (Fig. 5).

\section{Effect of Land Use/Cover Change on Water Yield}

The WY coefficients of the investigated LUC types exhibited substantial differences $(p<0.05)$, and water provision was prone to variations due to LUC change (Kocur-Bera 2018; Sharp et al. 2018). Therefore, the analysis demonstrated a 
Table 3 Water yield, actual and potential evapotranspiration from 1988 to 2018 in each LUC class

\begin{tabular}{|c|c|c|c|c|c|c|c|c|c|}
\hline \multicolumn{2}{|l|}{ Year } & \multirow{2}{*}{$\begin{array}{l}\text { Shrubland } \\
3078\end{array}$} & \multirow{2}{*}{$\begin{array}{l}\text { Cultivated land } \\
2934\end{array}$} & \multirow{2}{*}{$\frac{\text { Forest land }}{3883}$} & \multirow{2}{*}{$\begin{array}{l}\text { Grazing land } \\
2587\end{array}$} & \multirow{2}{*}{$\frac{\text { Woodland }}{2518}$} & \multirow{2}{*}{$\begin{array}{l}\text { Built-up land } \\
2200\end{array}$} & \multirow{2}{*}{$\begin{array}{l}\text { Bare land } \\
2400\end{array}$} & \multirow{2}{*}{$\frac{\text { Mean }}{2800}$} \\
\hline 1988 & WY & & & & & & & & \\
\hline & AET & 792 & 449 & 794 & 505 & 595 & 310 & 325 & 510 \\
\hline & PET & 799 & 553 & 607 & 511 & 590 & 314 & 336 & 501 \\
\hline \multirow[t]{3}{*}{1998} & WY & 2854 & 2798 & 4500 & 2754 & 2967 & 2987 & 3154 & 3145 \\
\hline & AET & 804 & 556 & 815 & 598 & 510 & 412 & 432 & 547 \\
\hline & PET & 808 & 560 & 732 & 572 & 514 & 420 & 447 & 536 \\
\hline \multirow[t]{3}{*}{2008} & WY & 2812 & 2754 & 5646 & 3040 & 3051 & 4200 & 4434 & 3705 \\
\hline & AET & 887 & 565 & 843 & 597 & 528 & 345 & 368 & 548 \\
\hline & PET & 896 & 569 & 757 & 580 & 539 & 354 & 378 & 539 \\
\hline \multirow[t]{3}{*}{2018} & WY & 2885 & 2867 & 6324.9 & 5484.9 & 4864.9 & 6764.9 & 5964.9 & 5130 \\
\hline & AET & 903 & 657 & 921 & 601 & 712 & 356 & 389 & 620 \\
\hline & PET & 917 & 662 & 929 & 609 & 720 & 367 & 397 & 628 \\
\hline \multicolumn{2}{|c|}{ Change WY } & -193 & -67 & 2442 & 2898 & 2347 & 4565 & 3565 & 2330 \\
\hline \multicolumn{2}{|c|}{ Change AET } & 213 & 208 & 127 & 96 & 117 & 46 & 64 & 110 \\
\hline \multicolumn{2}{|c|}{ Change PET } & 211 & 109 & 322 & 98 & 130 & 53 & 61 & 126 \\
\hline
\end{tabular}

WY: Water yield $\left(\mathrm{m}^{3} / \mathrm{ha}\right)$, AET: Mean actual evapotranspiration $(\mathrm{mm})$, PET: Potential evapotranspiration $(\mathrm{mm})$

significant variation in the water yield in each LUC type (Table 3). The rainfall-runoff characteristics, PET and AET of a basin can be modified by LUC change. It consequently affects the hydrological parameters of a watershed (Defersha and Melesse 2012). These can be a change of evapotranspiration, infiltration, water retention, and water availability (Sánchez-Canales et al. 2012). Based on the climate data for the four reference years, the simulated average AET and PET for different LUC types showed significant differences $(p<0.05)$.

The LUC change effects on water yield were not the same because the change of land use causes a change in soil properties and biodiversity, and then the underlying surface water, which affects runoff. This concentration process causes changes in the water cycle in the watershed, eventually affecting water yield (Lang et al. 2017).

This study shows that built-up and bare land water yield increased by $206.96 \%$ and $148.54 \%$, respectively. This could be due to the change in vegetation and conversion of land use into built-up and bare land. The increase in water yield intensity in the built-up and bare land was due to impervious surfaces deteriorating the infiltration and concentration time (Liu et al. 2013). Built-up land covered only $3.6 \%$ of the total area but accounted for around $42 \%$ of the total water provision in 2018 due to its high-water yield coefficient value (5).

However, the AET and PET were negatively correlated with the increase in built-up land. This contributes to more water yield in built-up land than in forest land. A similar report also shows that built-up land generates more water yield while land with vegetation cover triggers lower water yield (Im et al. 2009). Similar studies by Yang et al. (2013) and Zhao et al. (2017) show an increase of flooding in urban areas and that land not covered by vegetation cannot hold water in the soil for long. The analysis also shows that the water yield coefficient of built-up land and bare land was higher than for vegetated land, which indicates the absence of canopy that contributes to the lack of water infiltration, low evapotranspiration, and soil water retention (Arunyawat and Shrestha 2016; Jujnovsky et al. 2017).

Forest cover declined by $35.56 \%$ over the last three decades. However, the water yield in forests increased by $3042 \mathrm{~m}^{3}$ (63\%) between 1988 and 2018, which is still not as much as for built-up and bare land, because the forest has deep root systems and high permeability that facilitates storage of water as soil moisture in the pores of the soil and through interception by leaves. Due to the shade services of the forest, excessive sunlight that would cause more water loss in the underlying soil is also low. Therefore, the dissipation of water by evaporation in forest land is lower even if transpiration is higher. The water yield coefficient for forest land is also higher (3.8) compared with other LUC types because of the high infiltration, water-holding, and groundwater recharge capacity of forest land. This is supported by $\mathrm{Li}$ et al. (2018), who demonstrated that water yield increased after afforestation.

Cultivated land shows a low capability of interception and shallow root systems, and consumes a huge rate of water for the growth of crops, which leads to a substantial loss of water (Yang et al. 2020b). As a result, water provision in cultivated land was lower $\left(2885 \mathrm{~m}^{3} / \mathrm{ha}\right)$ as compared to forest land $\left(6925 \mathrm{~m}^{3} / \mathrm{ha}\right)$ in 2018 , which leads to the record lowest water yield coefficient (1.5) as compared to other land uses types due to low saturation and infiltration 
(no interception) and significant water loss in cultivated land. Although the cultivated land area increased by $14,838.4$ ha $(33 \%)$, its water provision declined by $67 \mathrm{~m}^{3} / \mathrm{ha}$ $(2.28 \%)$.

Most of the shrubland area was located in the Omo Gibe valley, which is a hot environment. Its area has declined dramatically due to agricultural expansion. As a result, the highest AET $(903 \mathrm{~mm})$ and PET $(917 \mathrm{~mm})$ were estimated in the model for shrubland. It furthermore led to the decline in water provision in shrubland by $6.27 \%$, from $3078 \mathrm{~m}^{3} / \mathrm{ha}$ in 1988 to $2885 \mathrm{~m}^{3} /$ ha in 2018 . Grazing land also declined by $49.12 \%$, whereas its water provision increased by $112 \%$. This might be due to significant infiltration in grazing land. Woodland area also increased by $4.25 \%$ in the last 30 years, and its water yield also increased by $23 \%$ (Table 4 ).

Each LUC change has demonstrated a correlation with a water yield change (Fig. 6). The Pearson correlation investigation showed that the forest land change was

Table 4 Comparison of water yield (WY) $\left(\mathrm{m}^{3}\right)$ caused by climate variability and LUC change

\begin{tabular}{llll}
\hline Year & $\begin{array}{l}\text { WY for LUC- } \\
\text { only scenario } \\
\left(10^{9}\right)\end{array}$ & $\begin{array}{l}\text { WY for climate } \\
\text { change-only } \\
\text { scenario }\left(10^{9}\right)\end{array}$ & $\begin{array}{l}\text { Water yield with } \\
\text { actual scenarios } \\
\left(10^{9}\right)\end{array}$ \\
\hline 1988 & 1.72 & 1.72 & 1.72 \\
1998 & 1.74 & 1.87 & 1.92 \\
2008 & 1.76 & 2.09 & 2.14 \\
2018 & 1.99 & 2.31 & 3.35 \\
\hline
\end{tabular}

negatively correlated with the water yield change (Fig. 6a) $(r=-0.78, p<0.05)$. The change in cultivated land was negatively correlated (Fig. 6b) with the change in water yield $(r=-0.67, p<0.05)$. Moreover, the change in water yield was positively correlated with the change in woodland. Grazing land and shrubland changes were negatively correlated with the water yield change. Built-up and bare land showed positive correlations with water yield changes $(r=0.82, p<0.05$ for built-up and $r=0.73, p<0.05$ for bare land).

\section{Climate Variability and LUC Change Effect on Water Provision}

The analysis showed that climate variability had more influence on water yield than LUC change (Table 5). The scenario without LUC changes (only climatic data analysis), substantially increased water yield in the Winike watershed by $68 \%$. This shows that the main factor for the increased water yield is climate variability. Furthermore, we observed a strong impact of precipitation on water yield in the watershed. The scenario that investigated the effect of LUC change (without climate data) revealed that water yield increased by $31 \%$, but it was not significant compared to the scenario for climate data. A similar study conducted by Dai et al. (2020), shows that water yield contributed by land use and climate variability increased by $26.94 \%$ and $73.06 \%$, respectively. Therefore, the study shows that climate variability was the main driving force for the spatial and temporal changes in water yield in the study area.
Fig. 6 Correlation of WY with LUC changes
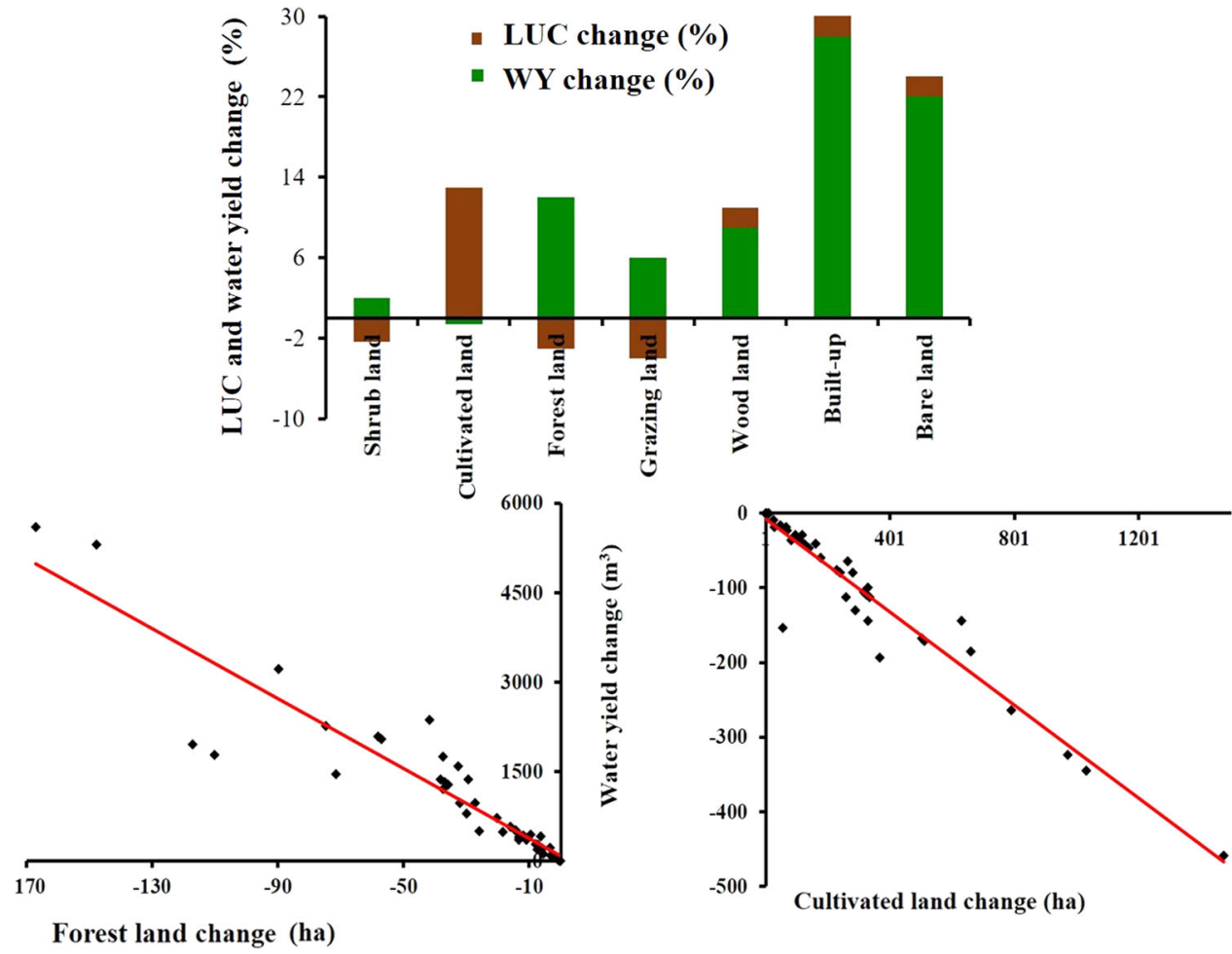
Table 5 The contribution of water from the watershed to the dams

\begin{tabular}{llllll}
\hline & Total water yield & \multicolumn{2}{l}{ Water consumption } & \multirow{2}{*}{ Realized supply model } \\
\cline { 3 - 5 } & & Industry & People & Animals & \\
\hline Amount $\left(\mathrm{m}^{3}\right)$ & $3 \times 10^{9}$ & $5 \times 10^{8}$ & $4 \times 10^{6}$ & $2 \times 10^{7}$ & $2.81 \times 10^{9}$ \\
Percent $(\%)$ & & 13.33 & 0.11 & 0.45 & 72.23 \\
\hline
\end{tabular}

\section{Watershed's Water Yield Contribution}

The Winike watershed contributes a substantial water yield to the hydropower generation found in the downstream part of the watershed even if exploited by human activities and affected by LUC change and climate variability. The average daily water consumption by a household was 79.77 liters $\left(0.080 \mathrm{~m}^{3}\right)$ (Table S3). The total annual water consumption by the human population in the watershed was $4.2 \times 10^{6} \mathrm{~m}^{3}\left(38.29 \mathrm{~m}^{3} /\right.$ ha/year) (Table 5).

The total daily and annual water consumption by livestock in the watershed was $48,250 \mathrm{~m}^{3}$, and $2 \times 10^{7} \mathrm{~m}^{3}$, respectively (Table S4), and the annual water extraction by the industry was $5.2 \times 10^{8} \mathrm{~m}^{3}$. This is a grave threat to the surrounding ecosystem and the downstream hydroelectric power plants by limiting the water delivery to the dams in the watershed.

The actual InVEST water yield model generated $3.35 \times$ $10^{9} \mathrm{~m}^{3}$ of water yield in the watershed (Table 4). The total consumed water by industry, people, and animals amounted to $5.4 \times 10^{8} \mathrm{~m}^{3}$. The analysis shows that the major consumers of water were the industry $(13.33 \%)$, followed by animals $(0.45 \%)$, and people $(0.11 \%)$. Therefore, the watershed water yield contribution to the hydropower generation was $2.8 \times 10^{9} \mathrm{~m}^{3}(72.22 \%)$ (Table 5). This indicates that the watershed has a vast water potential and can contribute to the downstream ecosystem conservation, but the climate change and extra exploitation of water by the business and human activities call for careful handling of the watershed.

\section{Model Sensitivity and Validation}

The analysis shows that the quantification of water yield is significantly sensitive to input climate data (precipitation and reference evapotranspiration). A $10 \%$ increase in precipitation generated an increase in water yield by $66 \%$, from $3345 \mathrm{~m}^{3} /$ ha to $5566 \mathrm{~m}^{3} / \mathrm{ha}$. Similarly, a $10 \%$ decline in precipitation generated a drop of $48 \%$. When $\mathrm{ET}_{0}$ increased by $10 \%$, water yield decreased by $18 \%$, and when $\mathrm{ET}_{0}$ decreased by $10 \%$, water yield increased by $7.6 \%$. This demonstrates that although $\mathrm{P}$ and $\mathrm{ET}_{0}$ had a significant impact on changes in water yield, precipitation had an even greater influence than $\mathrm{ET}_{0}$.

For a $10 \%$ increase in datasets of $K c$, AWC, and root depth, the model water yield decreased 0 to $2 \%$. As these input variables decreased by $10 \%$, water yield increased by 0 to $3 \%$. The analysis shows that the sensitivity of water yield to changes in $K c$, AWC, and root depth was insignificant. When the $Z$ factor (season factor) value changed from the baseline of 29-32, water yield decreased by $12 \%$. When the $Z$ value changed from the baseline of 29 to 0 , the water yield increased by $60 \%$. A change in the $Z$ factor from the baseline value of 29 to a value of 12 , increased the water yield by approximately $5.5 \%$. This shows that an increase in the value of the $\mathrm{Z}$ factor caused water yield to decrease.

Generally, the watershed water yield analyzed with the model is highly sensitive to the variation in values of some model input parameters and other model input parameters do not contribute to the variation in water yield to a large extent. In other words, for less decisive parameters, the model shows a little variation in the water yield due to their little impact.

The predicted water yield was consistent with the corresponding estimates from observed data $\left(R^{2}=0.91\right.$, RRSME $=0.92, \quad$ NSE $=0.85, P<0.01) \quad($ Table 6). The mean value of the observed and simulated water yield was $4687.75 \mathrm{~m}^{3} / \mathrm{ha}$ and $4494.47 \mathrm{~m}^{3} / \mathrm{ha}$, respectively, with a difference of $192.28 \mathrm{~m}^{3} / \mathrm{ha}$. The InVEST model could predict water yield with a low discrepancy, an error of $-2.1 \%$ (underestimation), suggesting that the LUC effects and its parameters were sufficiently recognized by the model for predicting the water yield in the study watershed. Therefore, $\mathrm{a} \pm 10 \%$ difference in the accuracy of the model is considered to be a very good rating for sensitivity analysis of this study, as suggested by Moriasi et al. (2007).

\section{Policy Implication}

Water yield in individual LUC types could contribute to consumptive water for the industry, people, animals, irrigation, and hydroelectric power generation (Brauman et al. 2007). There is also a probability of increasing flood (Rutkowska et al. 2017), causing erosion that affects downstream ecosystem services such as dams (Halecki et al. 2018). The reduction of excessive runoff is the main challenge for land-use planning and agricultural water resource management. This study recommends increasing forest land and reversing the conversion of vegetated land into built-up land and bare land because these land-use types could hinder permeability and maximize evaporation. Moreover, precipitation can increase in forest land because 
Table 6 Validation of the InVEST water yield model using the observed data

\begin{tabular}{|c|c|c|c|c|c|c|c|}
\hline Years & Stations & Observed & Predicted & PBIAS $^{\mathrm{a}}$ & $\mathrm{R}^{2}$ & RRSME $^{\mathrm{a}}$ & $\overline{N S E^{a}}$ \\
\hline \multirow[t]{5}{*}{1988} & Agena & 3483.59 & 3292.61 & -1.04 & 0.82 & 0.6 & 0.75 \\
\hline & Imdiber & 3309.41 & 3207.98 & -0.55 & 0.85 & 0.77 & 0.92 \\
\hline & Gunchre & 3916.15 & 4013.79 & -0.3 & 0.7 & 0.84 & 0.98 \\
\hline & Gumer & 4069.62 & 3427.12 & -0.49 & 0.77 & 0.63 & 0.57 \\
\hline & Merbe azernet & 3942.64 & 3879.2 & -0.35 & 0.87 & 0.8 & 0.96 \\
\hline \multirow[t]{5}{*}{1998} & Agena & 3976.6 & 3876.82 & -0.54 & 0.85 & 0.63 & 0.9 \\
\hline & Imdiber & 3976.6 & 4075.58 & -0.92 & 0.7 & 0.99 & 0.89 \\
\hline & Gunchre & 3988.22 & 3885.58 & -0.56 & 0.77 & 0.64 & 0.9 \\
\hline & Gumer & 4244.03 & 3809.58 & -0.91 & 0.87 & 0.65 & 0.74 \\
\hline & Merbe azernet & 4011.48 & 3917.99 & -0.51 & 0.77 & 0.88 & 0.83 \\
\hline \multirow[t]{5}{*}{2008} & Agena & 4623.08 & 4500.47 & -0.67 & 0.65 & 0.76 & 0.88 \\
\hline & Imdiber & 4677.35 & 4477.35 & -1.09 & 0.72 & 0.87 & 0.95 \\
\hline & Gunchre & 5219.96 & 5019.96 & -1.09 & 0.82 & 0.96 & 0.85 \\
\hline & Gumer & 4818.43 & 4585.87 & -1.09 & 0.82 & 0.94 & 0.96 \\
\hline & Merbe azernet & 4785.87 & 4707.53 & -0.61 & 0.85 & 0.75 & 0.89 \\
\hline \multirow[t]{6}{*}{2018} & Agena & 5968.77 & 5668.77 & -1.64 & 0.77 & 0.93 & 0.91 \\
\hline & Imdiber & 5860.25 & 5560.25 & -1.9 & 0.87 & 0.89 & 0.87 \\
\hline & Gunchre & 6185.82 & 5885.82 & -2.3 & 0.9 & 0.92 & 0.98 \\
\hline & Gumer & 6402.86 & 6102.86 & -2.6 & 0.85 & 0.97 & 0.91 \\
\hline & Merbe azernet & 6294.34 & 5994.34 & -2.74 & 0.87 & 0.91 & 0.95 \\
\hline & Average & 4687.75 & 4494.47 & -1.10 & 0.80 & 0.82 & 0.88 \\
\hline
\end{tabular}

a RRMSE = Residual Root Mean Square Error; NSE = Nash-Sutcliffe Efficiency; and PBIAS = Percentage Bias Error of micro-climatic interactions (Brauman et al. 2012). Many research findings also show that a decline in forest land results in an increase in flood peaks, annual flow, and flood volume (Kurowska et al. 2020; Rogatka et al. 2021; Romagnoli et al. 2018). Therefore, urgent conservation measures are required in the watershed to mitigate water yield stress caused by LUC and climate change and its effects. It is also essential to improve green policies such as conservation of forests or tree planting and implement Soil Water Conservation (SWC) to maintain water retention and maximize regulating capacities of ecosystems (Xu et al. 2017). This can be achieved by mass stakeholder's participation, maximization of indigenous ecological knowledge, implementation and improvement of environmental policy/law and boosting the awareness of the local community (Chodkowska-Miszczuk et al. 2021).

\section{Conclusions}

Omo gibe has a huge water resources potential, which leads to the construction of numerous hydropower dams in the lower parts of the basin and contributes to the improvement of the livelihood of the local community. However, many research finding shows that the dams and the associated ecosystem services will be damaged if appropriate conservation measurements are not implemented in the higher-altitude part of the basin or watersheds. The current challenges are catastrophic factors in the higher-altitude part of the basin, the Winike watershed, such as high population pressure, leading to the expansion of agriculture and removal of vegetation cover in search for traditional fuelwood, which resulted in deforestation and biodiversity loss. Therefore, the stakeholders responsible for managing and planning water resources should consider reducing the vegetation cover decline, introducing sustainable grazing, restoring and protecting water bodies, maximizing regreening, and reducing land degradation to maintain water resources in the basin.

The present research analyzed spatiotemporal changes in water yield in the Winike watershed from 1988 to 2018. Quantifying and mapping water provision is useful for the sustainable management of water resources and other related ecosystem services. In this study, the water yield rate of each LUC was analyzed using the InVEST water yield model.

This research also shows the effect of land use/cover change and climate variability on water yield. It is more affected by climate variability as compared to land use/ cover change. Moreover, the identification of factors that affect water yield more is important for the management of water resources. The analysis shows that precipitation had a 
more significant impact on the estimation of water yield compared to other climate factors.

This research also shows a spatial and temporal distribution of water yield by LUC type, which is helpful for saving time, energy and resources since it can be easily visualized on a map. It is important for the management of the land-use types to know the water yield potential of each land use/cover type, since some land-use types cause greater water loss.

The total annual water provision increased from $1.83 \times$ $10^{9} \mathrm{~m}^{3}$ in 1988 to $3.35 \times 10^{9} \mathrm{~m}^{3}$ in 2018 , which is an increase of $83.21 \%$ in the last 30 years. Sub-watersheds 31 , 32 , and 39 had the highest water yield, while subwatersheds 8, 29, and 30 had the lowest water yield. Built-up land had the highest water yield, followed by bare land and forest land. The InVEST model could predict water yield with a low error of $-2.1 \%$, suggesting that the LUC and climate factors are sufficiently recognized by the model. The InVEST water yield model estimation was consistent with the corresponding observed water yield from MOWIE data $(r=0.91, P<0.05)$. The watershed's water yield contributed to hydropower generation by $72 \%$; the remaining water was withdrawn by the industry, livestock, and people. This indicates the future threats for the water resource in the watershed. The analysis of water yield in sub-watersheds contributes to the management of small water supply, flood control, as well as hydropower production in the watershed. Our findings could be used to maintain and manage water resources in the watershed by engaging stakeholders regarding the considerable reduction of forest cover, increase in cultivated land, and other important land-use type conversions.

For determination of water yield, we recommended that the InVEST model is preferred as compared to SWAT and others models because SWAT is more time-consuming and computer-intensive in terms of data processing. Moreover, the InVEST water yield model is easier to use with fewer input data, and yet its output is more explanatory, understandable and easily interpretable. In addition, the output of the InVEST model can be shown at a pixel level (small area), whereas other models, such as SWAT, show the output at a hydrological response unit (sub-watershed) level, which is indicative of low precision. Therefore, the introduction of the InVEST water yield model is helpful for processing hydrological information on a landscape, which is important to determine which parts of the watershed have more degraded water situation. It also shows what factors affect water yield more in a sensitivity analysis. Therefore, the InVEST model is more appropriate to show sensitivity analysis.

Different projects associated with water resources might be designed for irrigation, dam construction, fish pond, water business companies, industry etc. Knowing the spatial water potential is important for such projects, saving time, energy, and resources for the stakeholders. Therefore, this research contributed to the design of projects associated with water resources, which encourages water development research.

Nature-based solutions are an increasingly popular approach to water resource management. Therefore, producing hydrological information on a landscape to inform decision-makers based on appropriate data is important and can help implement as a pilot project based on appropriate data. Moreover, ecosystems are interconnected, so preservation of the Winike watershed through a scientificallybased watershed development plan will ensure sustainability in the downstream ecosystem.

The basin is a significant contributor to the Ethiopian green economy by generating hydropower. Therefore, locally-initiated research, such as on the water yield potential of the Winike watershed, will contribute to achieving suitable development goals. Different types of projects must be implemented primarily at the local level to reduce vulnerabilities and build resilient communities to eventually solve global challenges. Therefore, such types of research help develop important local projects, which has a significant impact at a national, regional, and global level.

Moreover, spatial assessment of water yield helps planners and decision-makers identify the priority areas for conservation. Additionally, quantitative and qualitative assessment of water yield plays an important role in the socio-economic development of human societies as well as ecosystem health. This will help ensure the sustainability of the basin ecosystems.

\section{Availability of Data and Material}

Not applicable.

\section{Code Availability}

Not applicable.

Acknowledgements This paper was produced under scientific effort and cooperation carried out by Dr. Tomasz Noszczyk with Wolkite University and Addis Ababa University (Ethiopia). The authors would like to thank the two anonymous reviewers and Editor for their thorough work with the manuscript and for providing constructive and insightful comments on this paper. We are grateful to University of Agriculture in Krakow, Poland for their financial support of professional language correction. The authors would also like to express their gratitude to the native English speaker for linguistic support.

Author Contributions Abreham Berta Aneseyee - Conceptualization, Methodology, Software, Formal analysis, Investigation, Resources, Data Curation, Writing - Original Draft, Writing - Review \& Editing, Visualization, Teshome Soromessa - Conceptualization, Methodology, Validation, Formal analysis, Investigation, Writing - Original Draft, Supervision, Project administration, Funding acquisition' Eyasu 
Elias - Validation, Investigation, Resources, Data Curation, Writing Original Draft, Visualization, Supervision, Project administration, Tomasz Noszczyk - Methodology, Validation, Writing - Original Draft, Writing - Review \& Editing, Visualization, Supervision, Project administration, Funding acquisition, Gudina Legese Feyisa - Validation, Resources, Writing - Original Draft, Visualization, Supervision, Project administration

Funding Partial financial support was received from Addis Ababa University, Ethiopia. This work was financial supported by Polish Ministry of Education and Science for professional English language correction. Open access funding provided by University of Agriculture in Krakow, Poland.

\section{Compliance with Ethical Standards}

Conflict of Interest The authors declare that they have no conflict of interest.

Ethical Approval Not applicable.

Consent to Participate Not applicable.

Consent for Publication Not applicable.

Publisher's note Springer Nature remains neutral with regard to jurisdictional claims in published maps and institutional affiliations.

Open Access This article is licensed under a Creative Commons Attribution 4.0 International License, which permits use, sharing, adaptation, distribution and reproduction in any medium or format, as long as you give appropriate credit to the original author(s) and the source, provide a link to the Creative Commons license, and indicate if changes were made. The images or other third party material in this article are included in the article's Creative Commons license, unless indicated otherwise in a credit line to the material. If material is not included in the article's Creative Commons license and your intended use is not permitted by statutory regulation or exceeds the permitted use, you will need to obtain permission directly from the copyright holder. To view a copy of this license, visit http://creativecommons. org/licenses/by/4.0/.

\section{References}

Aghsaei H, Dinan NM, Moridi A, Asadolahi Z, Delavar M, Fohrer N, Wagner PD (2020) Effects of dynamic land use/land cover change on water resources and sediment yield in the Anzali wetland catchment, Gilan, Iran. Sci Total Environ 712:136449

Ahiablame L, Shakya R (2016) Modeling flood reduction effects of low impact development at a watershed scale. J Environ Manag 171:81-91

Allen RG, Pereira LS, Raes D, Smith M (1998) Crop evapotranspiration: Guidelines for computing crop water requirements. FAO Irrigation and drainage paper 56. FAO, Rome, Italy; 300: D05109

Aneseyee AB, Noszczyk T, Soromessa T, Elias E (2020) The InVEST habitat quality model associated with land use/cover changes: a qualitative case study of the winike watershed in the Omo-Gibe Basin, Southwest Ethiopia. Remote Sens 12:1103

Aneseyee AB, Soromessa T, Elias E (2020) The effect of land use/land cover changes on ecosystem services valuation of Winike watershed, Omo Gibe basin, Ethiopia. Hum Ecol Risk Assess 26:2608-2627
Arunyawat S, Shrestha RP (2016) Assessing land use change and its impact on ecosystem services in Northern Thailand. Sustainability $8: 768$

Assessment ME (2005) Ecosystems and human well-being. Island press, Washington, DC

Bai Y, Zheng H, Ouyang Z, Zhuang C, Jiang B (2013) Modeling hydrological ecosystem services and tradeoffs: a case study in Baiyangdian watershed, China. Environ Earth Sci 70:709-718

Bangash RF, Passuello A, Sanchez-Canales M, Terrado M, López A, Elorza FJ, Ziv G, Acuña V, Schuhmacher M (2013) Ecosystem services in Mediterranean river basin: climate change impact on water provisioning and erosion control. Sci Total Environ 458:246-255

Bastola S, Seong YJ, Lee SH, Jung Y (2019) Water yield estimation of the Bagmati basin of Nepal using GIS based InVEST model. J Korea Water Resour Assoc 52:637-645

Bian G, Du J, Song M, Xu Y, Xie S, Zheng W, Xu C-Y (2017) A procedure for quantifying runoff response to spatial and temporal changes of impervious surface in Qinhuai River basin of southeastern China. Catena 157:268-278

Bieger K, Hörmann G, Fohrer N (2015) The impact of land use change in the Xiangxi Catchment (China) on water balance and sediment transport. Regional Environ Change 15:485-498

Boithias L, Acuña V, Vergoñós L, Ziv G, Marcé R, Sabater S (2014) Assessment of the water supply: demand ratios in a Mediterranean basin under different global change scenarios and mitigation alternatives. Sci Total Environ 470:567-577

Brauman KA, Daily GC, Duarte TKE, Mooney HA (2007) The nature and value of ecosystem services: an overview highlighting hydrologic services. Annu Rev Environ Resour 32:67-98

Brauman KA, Freyberg DL, Daily GC (2012) Land cover effects on groundwater recharge in the tropics: ecohydrologic mechanisms. Ecohydrology 5:435-444

Budyko MI, Miller DH, Miller DH (1974) Climate and life. Academic press, New York, NY

Casagrande MFS, Furlan LM, Moreira CA, Rosa FTG, Rosolen V (2021) Non-invasive methods in the identification of hydrological ecosystem services of a tropical isolated wetland (Brazilian study case). Environ Chall 5:100233

Chaemiso SE, Abebe A, Pingale SM (2016) Assessment of the impact of climate change on surface hydrological processes using SWAT: a case study of Omo-Gibe river basin, Ethiopia. Modeling Earth Syst Environ 2:1-15

Chiang L-C, Chuang Y-T, Han C-C (2019) Integrating landscape metrics and hydrologic modeling to assess the impact of natural disturbances on ecohydrological processes in the Chenyulan watershed, Taiwan. Int J Environ Res Public Health 16:266

Chodkowska-Miszczuk J, Rogatka K, Lewandowska A (2021) The Anthropocene and ecological awareness in Poland: The postsocialist view. The Anthropocene Review, 1-30, Available online: https://doi.org/10.1177/20530196211051205 (online first)

Choto M, Fetene A (2019) Impacts of land use/land cover change on stream flow and sediment yield of Gojeb watershed, Omo-Gibe basin, Ethiopia. Remote Sens Appl: Soc Environ 14:84-99

Cochran S, Banner D (1977) Spall studies in uranium. J Appl Phys 48:2729-2737

Cudennec C, Leduc C, Koutsoyiannis D (2007) Dryland hydrology in Mediterranean regions-a review. Hydrological Sci J/J des Sci Hydrologiques 52:1077-1087

Dai E, Yin L, Wang Y, Ma L, Tong M (2020) Quantitative Assessment of the Relative Impacts of Land Use and Climate Change on the Key Ecosystem Services in the Hengduan Mountain Region, China. Sustainability 12:4100

Defersha MB, Melesse AM (2012) Field-scale investigation of the effect of land use on sediment yield and runoff using runoff plot data and models in the Mara River basin. Kenya Catena 89:54-64 
Dimobe K, Ouédraogo A, Soma S, Goetze D, Porembski S, Thiombiano A (2015) Identification of driving factors of land degradation and deforestation in the Wildlife Reserve of Bontioli (Burkina Faso, West Africa). Glob Ecol Conserv 4:559-571

Donohue RJ, Roderick ML, McVicar TR (2012) Roots, storms and soil pores: Incorporating key ecohydrological processes into Budyko's hydrological model. J Hydrol 436:35-50

Dwarakish G, Ganasri B (2015) Impact of land use change on hydrological systems: A review of current modeling approaches. Cogent Geosci 1:1115691

Estifanos TH, Gebremariam B (2019) Modeling-impact of Land Use/ Cover Change on Sediment Yield (Case Study on Omo-gibe Basin, Gilgel Gibe III Watershed, Ethiopia). Am J Mod Energy 5:84-93

Fu B (1981) On the calculation of the evaporation from land surface. Sci Atmos Sin 5:23-31

Gain AK, Wada Y (2014) Assessment of future water scarcity at different spatial and temporal scales of the Brahmaputra River Basin. Water Resour Manag 28:999-1012

Gebremicael T, Mohamed Y, Betrie G, Van der Zaag P, Teferi E (2013) Trend analysis of runoff and sediment fluxes in the Upper Blue Nile basin: A combined analysis of statistical tests, physically-based models and landuse maps. J Hydrol 482:57-68

Ghaffari G, Keesstra S, Ghodousi J, Ahmadi H (2010) SWAT-simulated hydrological impact of land-use change in the Zanjanrood basin, Northwest Iran. Hydrological Process: Int J 24:892-903

Guo D, Westra S, Maier HR (2016) An R package for modelling actual, potential and reference evapotranspiration. Environ Model Softw 78:216-224

Guswa AJ (2008) The influence of climate on root depth: A carbon cost-benefit analysis. Water Resour Res 44, https://doi.org/10. 1029/2007WR006384

Gwate O, Woyessa Y, Wiberg D (2015) Dynamics of land cover and impact on streamflow in the Modder River Basin of South Africa: case study of a Quaternary catchment. Int J Environ Prot Policy 3:31-38

Gyamfi C, Ndambuki JM, Salim RW (2016) Application of SWAT model to the Olifants Basin: calibration, validation and uncertainty analysis. J Water Resour Prot 8:397

Halecki W, Kruk E, Ryczek M (2018) Loss of topsoil and soil erosion by water in agricultural areas: A multi-criteria approach for various land use scenarios in the Western Carpathians using a SWAT model. Land Use Policy 73:363-372

Hamel P, Guswa AJ (2015) Uncertainty analysis of a spatially explicit annual water-balance model: case study of the Cape Fear basin, North Carolina. Hydrol Earth Syst Sci 19:839-853

Hargreaves GH, Allen RG (2003) History and evaluation of Hargreaves evapotranspiration equation. J Irrig Drain Eng 129:53-63

Ibrahim B, Wisser D, Barry B, Fowe T, Aduna A (2015) Hydrological predictions for small ungauged watersheds in the Sudanian zone of the Volta basin in West Africa. J Hydrol: Regional Stud 4:386-397

Im S, Kim H, Kim C, Jang C (2009) Assessing the impacts of land use changes on watershed hydrology using MIKE SHE. Environ Geol 57:231

Jujnovsky J, Ramos A, Caro-Borrero Á, Mazari-Hiriart M, Maass M, Almeida-Leñero L (2017) Water assessment in a peri-urban watershed in Mexico City: A focus on an ecosystem services approach. Ecosyst Serv 24:91-100

Kocur-Bera K (2018) Impact of land use on climate change, Proceedings of the International Scientific Conference Engineering for Rural Development, Jelgava, 23-25.05.2018, 457-462. https://doi.org/10.22616/ERDev2018.17.N036

Komi K, Neal J, Trigg MA, Diekkrüger B (2017) Modelling of flood hazard extent in data sparse areas: a case study of the Oti River basin, West Africa. J Hydrol: Regional Stud 10:122-132
Kurowska K, Kryszk H, Marks-Bielska R, Mika M, Leń P (2020) Conversion of agricultural and forest land to other purposes in the context of land protection: Evidence from Polish experience. Land Use Policy 95:104614

Lang Y, Song W, Zhang Y (2017) Responses of the water-yield ecosystem service to climate and land use change in Sancha River Basin, China. Phys Chem Earth, Parts A/B/C 101:102-111

Lepeška T, Wojkowski J, Wałęga A, Młyński D, Radecki-Pawlik A, Olah B (2020) Urbanization-Its Hidden Impact on Water Losses: Prądnik River Basin, Lesser Poland. Water 12:1958

Li S, Yang H, Lacayo M, Liu J, Lei G (2018) Impacts of land-use and land-cover changes on water yield: A case study in Jing-Jin-Ji, China. Sustainability 10:960

Liu Y, Zhang X, Xia D, You J, Rong Y, Bakir M (2013) Impacts of land-use and climate changes on hydrologic processes in the Qingyi River watershed, China. J Hydrologic Eng 18:1495-1512

Lotz T, Opp C, He X (2018) Factors of runoff generation in the Dongting Lake basin based on a SWAT model and implications of recent land cover change. Quat Int 475:54-62

Lüke A, Hack J (2018) Comparing the applicability of commonly used hydrological ecosystem services models for integrated decisionsupport. Sustainability 10:346

Martín-López B, Gómez-Baggethun E, García-Llorente M, Montes C (2014) Trade-offs across value-domains in ecosystem services assessment. Ecol Indic 37:220-228

McGlynn B, Blöschl G, Borga M, Bormann H, Hurkmans R, Komma J, Nandagiri L, Uijlenhoet R, Wagener T (2012) A data acquisition framework for prediction of runoff in ungauged basins. Predictions in Ungauged Basins, IAHS, 29-52

McMahon T, Peel M, Lowe L, Srikanthan R, McVicar T (2013) Estimating actual, potential, reference crop and pan evaporation using standard meteorological data: a pragmatic synthesis. Hydrol Earth Syst Sci 17:1331-1363

Mekonnen MM, Hoekstra AY (2011) The green, blue and grey water footprint of crops and derived crop products. Hydrol Earth Syst Sci 15:1577-1600

Moriasi DN, Arnold JG, Van Liew MW, Bingner RL, Harmel RD, Veith TL (2007) Model evaluation guidelines for systematic quantification of accuracy in watershed simulations. Trans ASABE 50:885-900

Munoth P, Goyal R (2019) Impacts of land use land cover change on runoff and sediment yield of Upper Tapi River Sub-Basin. International Journal of River Basin Management, India, p 1-13

Murphy, A., Kapelle, D., 2014. Scaling up investment for ecosystem services to meet the global water crisis. Report presented to Nature Conservation Research Centre, Accra

Narsimlu B, Gosain AK, Chahar BR (2013) Assessment of future climate change impacts on water resources of Upper Sind River Basin, India using SWAT model. Water Resour Manag 27:3647-3662

Nasta P, Palladino M, Ursino N, Saracino A, Sommella A, Romano N (2017) Assessing long-term impact of land-use change on hydrological ecosystem functions in a Mediterranean upland agro-forestry catchment. Sci Total Environ 605:1070-1082

Redhead J, Stratford C, Sharps K, Jones L, Ziv G, Clarke D, Oliver T, Bullock J (2016) Empirical validation of the InVEST water yield ecosystem service model at a national scale. Sci Total Environ 569:1418-1426

Ren Y, Lu L, Zhang H, Chen H, Zhu D (2020) Residents' willingness to pay for ecosystem services and its influencing factors: A study of the Xin'an River basin. J Clean Prod 268:122301

Rogatka K, Starczewski T, Kowalski M (2021) Urban resilience in spatial planning of polish cities-True or false? Transformational perspective. Land Use Policy, 101:105172

Romagnoli M, Moroni S, Recanatesi F, Salvati R, Mugnozza GS (2018) Climate factors and oak decline based on tree-ring 
analysis. A case study of peri-urban forest in the Mediterranean area. Urban Forestry Urban Green 34:17-28

Rutkowska A, Willems P, Niedzielski T (2017) Relation between design floods based on daily maxima and daily means: use of the Peak Over Threshold approach in the Upper Nysa Kłodzka Basin (SW Poland). Geomat, Nat Hazards Risk 8:585-606

Sahle M, Saito O, Fürst C, Yeshitela K (2019) Quantifying and mapping of water-related ecosystem services for enhancing the security of the food-water-energy nexus in tropical data-sparse catchment. Sci Total Environ 646:573-586

Sánchez-Canales M, Benito AL, Passuello A, Terrado M, Ziv G, Acuña V, Schuhmacher M, Elorza FJ (2012) Sensitivity analysis of ecosystem service valuation in a Mediterranean watershed. Sci Total Environ 440:140-153

Schröter D, Cramer W, Leemans R, Prentice IC, Araújo MB, Arnell NW, Bondeau A, Bugmann H, Carter TR, Gracia CA (2005) Ecosystem service supply and vulnerability to global change in Europe. science 310:1333-1337

Scordo F, Lavender TM, Seitz C, Perillo VL, Rusak JA, Piccolo M, Perillo GM (2018) Modeling water yield: Assessing the role of site and region-specific attributes in determining model performance of the InVEST seasonal water yield model. Water 10:1496

Sharma S, Nahid S, Sharma M, Sannigrahi S, Anees MM, Sharma R, Shekhar R, Basu AS, Pilla F, Basu B, Joshi PK (2020) A longterm and comprehensive assessment of urbanization-induced impacts on ecosystem services in the capital city of India. City Environ Interact 7:100047

Sharp, R., Tallis, H., Ricketts, T., Guerry, A., Wood, S., ChaplinKramer, R., Nelson, E., Ennaanay, D., Wolny, S., Olwero, N., 2018. InVEST 3.6. 0 user's guide. The Natural Capital Project, University of Minnesota, The Nature Conservancy, and World Wildlife Fund

Shi D, Shi Y, Wu Q (2021) Multidimensional assessment of lake water ecosystem services using remote sensing. Remote Sens 13:3540

Shi Y, Shi D, Zhou L, Fang R (2020) Identification of ecosystem services supply and demand areas and simulation of ecosystem service flows in Shanghai. Ecol Indic 115:106418

Shoyama K, Yamagata Y (2014) Predicting land-use change for biodiversity conservation and climate-change mitigation and its effect on ecosystem services in a watershed in Japan. Ecosyst Serv 8:25-34

Singh VP, Singh P, Haritashya UK (2011) Encyclopedia of snow, ice and glaciers. Springer Science \& Business Media, Springer, Dordrecht, https://doi.org/10.1007/978-90-481-2642-2

Sileshi Z, Tegegne A, Tsadik GT (2003) Water resources for livestock in Ethiopia: Implications for research and development. Integrated water and land management research and capacity building priorities for Ethiopia 66

Srichaichana J, Trisurat Y, Ongsomwang S (2019) Land Use and Land Cover Scenarios for Optimum Water Yield and Sediment Retention Ecosystem Services in Klong U-Tapao Watershed, Songkhla, Thailand. Sustainability 11:2895

Stosch KC, Quilliam RS, Bunnefeld N, Oliver DM (2017) Managing multiple catchment demands for sustainable water use and ecosystem service provision. Water 9:677

Szewrański S, Chruściński J, Kazak J, Świąder M, TokarczykDorociak K, Żmuda R (2018) Pluvial Flood Risk Assessment Tool (PFRA) for rainwater management and adaptation to climate change in newly urbanised areas. Water 10:386
Takalaa, W., Tamamc, D., 2016. The effects of land use land cover change on hydrological process of Gilgel Gibe, Omo Gibe Basin, Ethiopia. Int. J. Sci. Eng. Res 7

Tallis H, Ricketts T, Guerry A, Nelson E, Ennaanay D, Wolny S, Olwero N, Vigerstol K, Pennington D, Mendoza G (2011) InVEST 2.1 beta user's guide. the natural capital project, Stanford

Vardon M, Keith H, Lindenmayer D (2019) Accounting and valuing the ecosystem services related to water supply in the Central Highlands of Victoria, Australia. Ecosyst Serv 39:101004

Vogl AL, Dennedy-Frank PJ, Wolny S, Johnson JA, Hamel P, Narain U, Vaidya A (2016) Managing forest ecosystem services for hydropower production. Environ Sci Policy 61:221-229

Walega A, Salata T (2019) Influence of land cover data sources on estimation of direct runoff according to SCS-CN and modified SME methods. Catena 172:232-242

Xie G, Zhang C, Zhen L, Zhang L (2017) Dynamic changes in the value of China's ecosystem services. Ecosyst Serv 26:146-154

Xu L, Ouyang W, Qian Y, Su C, Su J, Chen H (2016) Highthroughput profiling of antibiotic resistance genes in drinking water treatment plants and distribution systems. Environ Pollut 213:119-126

Xu W, Xiao Y, Zhang J, Yang W, Zhang L, Hull V, Wang Z, Zheng H, Liu J, Polasky S (2017) Strengthening protected areas for biodiversity and ecosystem services in China. Proc Natl Acad Sci 114:1601-1606

Xu X, Liu W, Scanlon BR, Zhang L, Pan M (2013) Local and global factors controlling water-energy balances within the Budyko framework. Geophys Res Lett 40:6123-6129

Yan R, Zhang X, Yan S, Zhang J, Chen H (2018) Spatial patterns of hydrological responses to land use/cover change in a catchment on the Loess Plateau, China. Ecol Indic 92:151-160

Yang C, Yu Z, Hao Z, Lin Z, Wang H (2013) Effects of vegetation cover on hydrological processes in a large Region: Huaihe River Basin, China. J Hydrologic Eng 18:1477-1483

Yang Q, Liu G, Giannetti BF, Agostinho F, Almeida CM, Casazza M (2020a) Emergy-based ecosystem services valuation and classification management applied to China's grasslands. Ecosyst Serv 42:101073

Yang X, Chen R, Meadows ME, Ji G, Xu J (2020b) Modelling water yield with the InVEST model in a data scarce region of northwest China. Water Supply 20:1035-1045

Yang Y, Donohue RJ, McVicar TR (2016) Global estimation of effective plant rooting depth: Implications for hydrological modeling. Water Resour Res 52:8260-8276

Zhang B, Song X, Zhang Y, Han D, Tang C, Yu Y, Ma Y (2012) Hydrochemical characteristics and water quality assessment of surface water and groundwater in Songnen plain, Northeast China. Water Res 46:2737-2748

Zhang Y, Kendy E, Qiang Y, Changming L, Yanjun S, Hongyong S (2004) Effect of soil water deficit on evapotranspiration, crop yield, and water use efficiency in the North China Plain. Agric water Manag 64:107-122

Zhao G, Mu X, Jiao J, An Z, Klik A, Wang F, Jiao F, Yue X, Gao P, Sun W (2017) Evidence and causes of spatiotemporal changes in runoff and sediment yield on the Chinese Loess Plateau. Land Degrad Dev. 28:579-590

Zhou W, Liu G, Pan J, Feng X (2005) Distribution of available soil water capacity in China. J Geographical Sci. 15:3-12 